UDC 547.305+547.311

\title{
ADDUCTS OF SUBSTITUTED VINYLOXYCYCLOPRFOPANES WITH THIOLS AS THERMOSTABILIZERS OF PVC
}

\author{
R.Z. Shahnazarli \\ Institute of Polymer Materials of the National Academy of Sciences of Azerbaijan \\ AZ 5004, Sumgait, S. Vurgun str.,124.e-mail: shahnazarli@mail.ru
}

Received 17.08.2021

Accepted 25.11.2021

\begin{abstract}
The compositions on the basis of PVC, containing dioctyl phthalate as a plasticizer, complex thermal stabilizers - calcium and zinc stearates and adducts of thiophenol and ethanedithiol with gemdiglycidyloxymethylsubstituted cyclopropylvinyl ether as co-stabilizers and biocidal additives were developed. Thermal properties of the developed compositions were investigated and the influence of the synthesized sulfur-containing adducts on the thermal stability and color change of the compositions studied. The tests were carried out to reveal the antifungal activity of adducts in the structure of PVC compositions. It found that the chemical structure of adducts after introduction into the structure of compositions was not essentially changed. The compositions with the participation of adducts as co-stabilizers acquired improved indices on thermal stability, color stability and antifungal activity.

Keywords: vinyloxycyclopropane, ethanediol, thiophenol, adduct, polyvinyl chloride, composition, thermal stability, color stability, fungal activity.
\end{abstract}

DOI: 10.32737/2221-8688-2021-3-186-195

\section{Introduction}

One of the widely used polymers for the creation of many composition PM is PVC which has high mechanical properties and good chemical resistance and inertness in relation to the biological medium [1,2]. On the basis of PVC (and also vinyl chloride copolymers), new materials and products used in daily life, medicine, instrumentation, automobile industry, etc. are obtained [3]. As a rule, PVC compositions are multicomponent systems, including various additives: stabilizers, plasticizers, softeners, fillers, etc [4,5]. The content of these additives can be changed in sufficiently wide ranges. The unstabilized PVC is very sensitive to the heat and light effects, therefore, its processing and exploitation is practically impossible without additional stabilization. A characteristic feature of thermal destruction of PVC is changes of its color from light yellow to dark brown. Thermal destruction of PVC is a chain process proceeding on a radical or ionic mechanism with the breaking of $\mathrm{C}-\mathrm{H}-$ or C-Cl-bond [6,7]. The isolated $\mathrm{HCl}$ catalyzes the further dehydrochlorination, accompanied by the formation of polyene structures and change of color of PVC compositions:

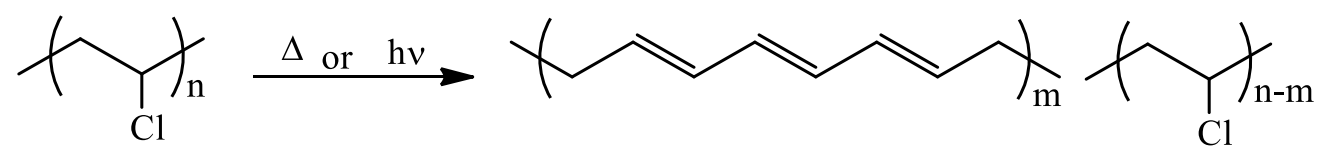

Besides dehydrochlorination, PVC compositions have another property - low fungal resistance, which somewhat limits the area of their application. The biological protection of various polymer materials is important not only from a hygienic point of view; it also has important ecological and economic significance, because the preservation of materials from the destructive action of microorganisms favors the improvement of a quality of human habitation and resource saving [8]. In this regard, recently a growing interest to antimicrobial polymer materials used in the medical and food industries is observed [9]. 
Among the compounds with antimicrobial action, the metal-containing biostabilizers tinorganic compounds and silver compounds, polyphosphonates, poly-N-halogenpyridine, poly-(styrene-divinylbenzene)-sulfamide, isothiazolines and other sulfur-containing compounds are known [10,11]. The silver and zinc compounds as the compounds with very low level of toxicity are mainly used as inorganic antimicrobial modifiers [12]. The natural antimicrobial modifiers are usually combined with additives increasing compatibility with the polymer and regulating their migration to the surface of the product [13]. The stabilizer used for prevention of the dehydrochlorination process should have a number of positive properties: it must be colorless, compatible and not migrate from the polymer matrix, be inexpensive and non-toxic, odorless, should not influence on the physicalmechanical and rheological properties of the polymer [14].

With the aim of increase of the thermal stability of compositions based on plasticized PVC, the sulfur-containing adducts of substituted cyclopropylvinyl esters with geminal glycidyloxymethyl substituents in a threemembered cycle were synthesized and tested as functional additives to compositions. The synthesized adducts were tested as co-stabilizers together with calcium and zinc stearates. The influence of the duration of thermal action on changes of PVC compositions color was analyzed and the tests for their antimicrobial activity also carried out.

\section{Experimental part}

\section{Materials}

Polyvinyl chloride of suspension mark Petvinil-S-39/71 (Petkim, Turkey); the additional purification of the polymer was carried out by multiple washing with ethyl alcohol and diethyl ether, with the subsequent drying under vacuum $\left(25^{\circ} \mathrm{C}, 10 \mathrm{~Pa}\right)$; ester plasticizer - dioctyl phthalate (DOPh) (LG Chemical, Rep. Korea); complex thermostabilizers - Ca stearate $\mathrm{Ca}\left(\mathrm{CaSt}_{2}\right)-$ ACSABCA-3 and $\mathrm{Zn}$ stearate $\mathrm{Zn}\left(\mathrm{ZnSt}_{2}\right)$ ACSABZN-53 (Akdeniz Kimyasal Kunler, Turkey); initiator - azo-bis-isobutyronitrile (AIBN) was recrystallized from methanol before use; the solvents were distilled and dried according to standard methods before use.

\section{Methods of investigation}

The IR spectra of the synthesized ethers and the adducts obtained from them were taken on IR-Fourier spectrophotometer "ALPHA" of firm Brukers (Germany) in the wave number range of $600-4000 \mathrm{~cm}^{-1}$ in $\mathrm{KBr}$ prisms as the thin films. The purity of the synthesized compounds was determined by gas-liquid chromatography.

The thermal stability of PVC films was evaluated on the induction period time (time before isolation of $\mathrm{HCl}$ ) according to GOST 14041-91 at temperature $180^{\circ} \mathrm{C}$. The films were made from a homogeneous mixture of stabilizer with PVC: the stabilizer was introduced into concentrated PVC solution as a suspension in the presence of DOPh. After evaporation of the solvent, the film was obtained. Thermal treatment of the films was performed both in a nitrogen atmosphere and in air.

The dehydrochlorination rate of PVC was determined on the quantity of $\mathrm{HCl}$ isolated during thermal treatment of the samples. The quantities of the isolated $\mathrm{HCl}$ were determined by titration by $0,01 \mathrm{~N} \mathrm{NaOH}$ solution in the presence of an indicator (a mixture of 1 part of $0.2 \%$ of methyl red solution in acetone and 1 part of $0.1 \%$ of methylene blue solution in ethanol). The indicator paper "congo-red" was prepared by impregnation of filter paper with an indicator solution in a mixture of $0.5 \mathrm{ml}$ of distilled water with $200 \mathrm{ml}$ of glycerin.

The color stability (time to the composition darkening) was determined through sharp color changes at $180^{\circ} \mathrm{C}$. The fungal stability of the compositions was determined according to GOST 9.049-91.

The migration (release) of adducts from PVC composition was determined in line with GOST 14926-81. The mass fraction of volatiles was determined according to GOST 8728-88. The water absorption of the composition samples in cold and boiling water was determined according to GOST 4650-80.

Synthesis of 1-vinyloxy-2,2'diglycidyloxymethyl cyclopropane. 
The epoxy-containing compound of 1vinyloxy-2,2'-diglycidyloxymethyl

cyclopropane was synthesized on methodology and shown in [15].

\section{Addition of thiols to gem - diglycidyloxymethyl substituted vinyloxycyclopropane.}

The addition of thiols (thiophenol and ethanedithiol) to gem-disubstituted vinyloxycyclopropane was carried out in the radical conditions on methodology similar to [16]. In case of addition to thiophenol esters, the ratio of reagents was $1: 1$, in a case of addition of ethandithiol, the ratio of ether and ethandithiol was $2: 1$. The initiator of the radical reaction was azo-bis-isobutyronitrile (AIBN) in a quantity of 0.5 mass $\%$ of the stoichiometric quantity of reagents. The reaction was carried out at temperature $70^{\circ} \mathrm{C}$. To complete the conversion of vinyl groups, thiols were taken in a small excess in relation to vinyl ether (5\% excess).

At the end of the reaction, the ampoule was opened. The obtained sulfur-containing adducts were washed in 3-4 times with $10 \%$ soda solution to remove thiol excess. The washed product was extracted with ether and dried over $\mathrm{Na}_{2} \mathrm{SO}_{4}$. The ether was distilled off in a water bath, and the residues were distilled in a vacuum. Yield of reaction products - 93-97\%.

Making of compositions on the basis of PVC

The compositions were made by rolling of a mixture consisting of 60 mass p. of PVC and 40 mass p. of DOPh (control samples), complex stabilizers - $\mathrm{Ca} / \mathrm{Zn}$-stearates $\left(\mathrm{CaSt}_{2} ; \mathrm{ZnSt}_{2}\right)$ with addition of 2,0 mass $p$. of the synthesized adducts. The components of the compositions were thoroughly mixed, gelatinized by keeping them in a drying oven at $80^{\circ} \mathrm{C}$ for $40 \mathrm{~min}$. and rolled at $150^{\circ} \mathrm{C}$ for $10 \mathrm{~min}$. The rolled sheets were pressed to a thickness of $1.0 \pm 0.1 \mathrm{~mm}$ at press pressure of $1.0 \cdot 10^{6}$ at first for $10 \mathrm{~min}$., then, without removing the pressure, the plates were cooled to $30-40^{\circ} \mathrm{C}$, after reducing the pressure, they were removed from the mold. The samples as bands with size of $6 \times 40 \times 2 \mp 0,2 \mathrm{~mm}$ and disks with $\emptyset 0,8 \mathrm{Mm}$ were cut out of the obtained plates for study of the thermal stability of the compositions $[17,18]$.

\section{Results and discussion}

By interaction reaction with thiols, the sulfur-containing adducts of vinyl cyclopropyl esters with geminal glycidyloxymethyl substituents were obtained in a three-membered cycle. Under radical conditions, the addition reaction of thiols on double bonds of vinyl esters was over in 30 minutes which was confirmed by the data of spectral (IR and PMR) analyses (Fig.1). The preparation reaction of adducts proceeds according to the scheme presented below:

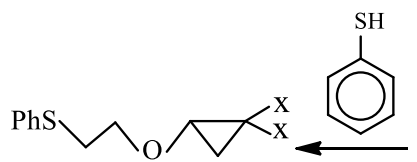

adduct $\mathbf{a}$

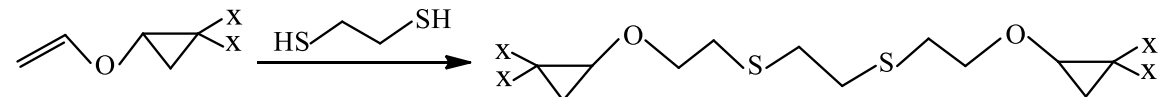

$\mathrm{x}=\widehat{\mathrm{O}} \widehat{\mathrm{O}}$ adduct $\mathbf{b}$
The synthesized sulfur-containing adducts a and b are sufficiently stable compounds, externally they are viscous oily liquids of straw color.
Some of their properties are presented in Table 1.

Table 1. Some properties of adducts of gem-disubstituted cyclopropyl vinyl esters with thiophenol (structure a) and ethanediol (structure b).

\begin{tabular}{|c|c|c|}
\hline \multirow{2}{*}{ Name of indices } & \multicolumn{2}{|c|}{ Adducts } \\
\hline & $\mathbf{a}$ & $\mathbf{b}$ \\
\hline Coloration & \multicolumn{2}{|c|}{ Light-yellow } \\
\hline
\end{tabular}




\begin{tabular}{|l|c|c|}
\hline Density at $20^{\circ} \mathrm{C}, \mathrm{g} / \mathrm{cm}^{3}$ & 0.9428 & 0.9352 \\
\hline Refraction index at $20^{\circ} \mathrm{C}$ & 1.4477 & 1.4432 \\
\hline Acid number $\mathrm{mg} \mathrm{KOH} / \mathrm{g}$ & 0.08 & 0.07 \\
\hline Viscosity at $20^{\circ} \mathrm{C}, \mathrm{cPZ}$ & 12.64 & 12.48 \\
\hline Congelation temperature, ${ }^{\circ} \mathrm{C}$ & -48 & -53 \\
\hline Flash temperature, ${ }^{\circ} \mathrm{C}$ & 219 & 224 \\
\hline Content of volatiles, $\%$ (at $100^{\circ} \mathrm{C}$ for $\left.6 \mathrm{~h}\right)$ & 0.063 & 0.068 \\
\hline
\end{tabular}

The investigation of the addition reaction of thiols to vinyl cyclopropyl ether showed that the geminal glycidyloxymethyl substituents located at the cyclopropane ring do not essentially influence on the course of the reaction and the yields of the obtained adducts are quite high (about 93-97\%).

It was established on the basis of data of spectral and chemical analyses that the synthesized adducts had a composition $1: 1$ in a case of thiilation reaction of thiphenols. Since ethandithiol was a bifunctional compound and a double quantity of vinyl ether was consumed for the formation of adduct, the adduct composition had a ratio of 2:1. The elemental analysis of the obtained adducts and data of IR and PMR spectroscopy showed that the addition proceeds regioselectively as the addition of 1,2-addition of vinylcyclopropyl ether with formation of mono- and bis-adduct $\mathbf{a}$ and $\mathbf{b}$.

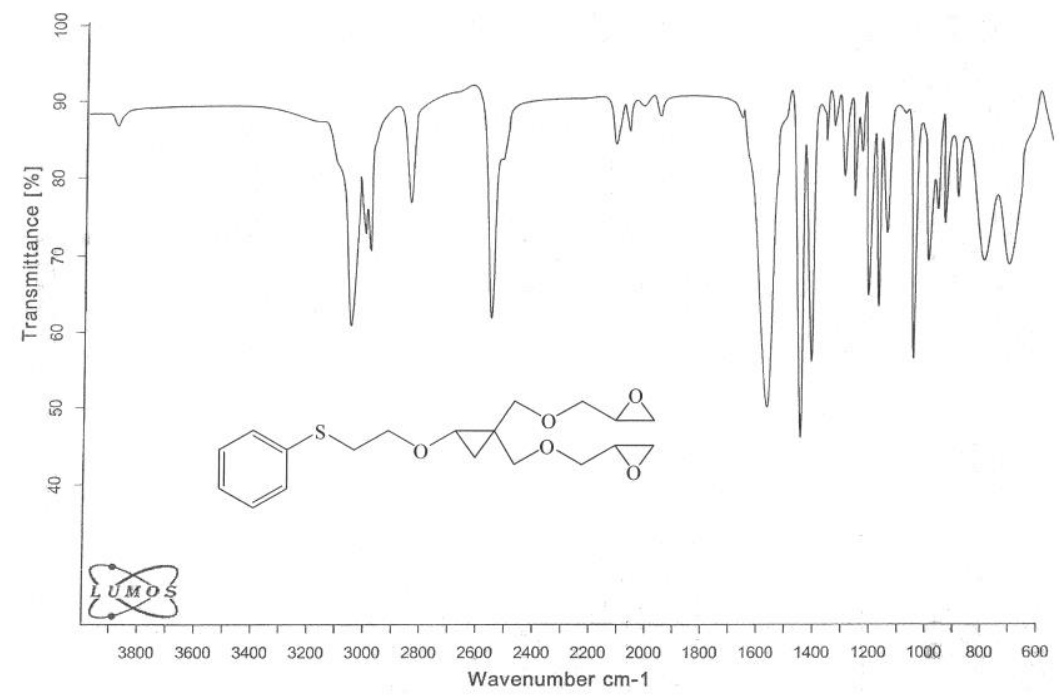

Fig. 1. IR spectrum of adduct of 1-vinyloxy-2,2'-diglycidyloxymethylcyclopropane with thiophenol.

The analysis of the spectral data of the synthesized compounds revealed the availability of characteristic absorption bands of separate fragments and groups. In the IR spectra of the isolated adducts, the absorption bands in the field of 1020-1040 $\mathrm{cm}^{-1}$, characteristic for the cyclopropane ring were observed. The disappearance of the characteristic absorption bands of the vinyl group in the field of $1640 \mathrm{~cm}^{-}$ 1 , as well as the appearance of new absorption bands of the valence vibrations of $\mathrm{CH}_{2}-\mathrm{S}$ bond in the field of $630-640 \mathrm{~cm}^{-1}$, allowed to assume that the addition of thiols proceeds selectively with high degree, i.e., the addition proceeded only on the double bond of vinyl ether. The analysis of the PMR spectra of these adducts showed the absence of proton signals in the double bond in of $\delta=5.0-6.0 \mathrm{ppm}$ and the appearance of new signals - protons of $\mathrm{SCH}_{2}-$ groups in the field of $\delta=2,62-2.96 \mathrm{ppm}$. According to the values of chemical shifts, the character of spin-spin interaction and integral intensities, these signals correspond to the structures of mono- and bis-adducts containing three-membered cycles.

It should be noted that the structural changes of adducts after their introduction into the composition (Fig.3) are not observed. In the IR spectra of PVC stabilized with 2,0 mass p. of adducts, the absorption bands in the field of 
625-645 $\mathrm{cm}^{-1}$ and 1150-1060 $\mathrm{cm}^{-1}$, characteristic for vibrations of the mercaptogroup and ether bond are respectively observed. In the spectra, the absorption bands of symmetric valence vibrations of epoxide groups at $760-855 \mathrm{~cm}^{-1}$, and also the absorption bands in the field of $1000-1020 \mathrm{~cm}^{-1}$ and $3060 \mathrm{~cm}^{-1}$, attributed to skeleton vibrations of threemembered cycle, the bands in the field of 1420$1500 \mathrm{~cm}^{-1}$ and the wide band at $1600 \mathrm{~cm}^{-1}$ characteristic for aromatic fragment are also observed.

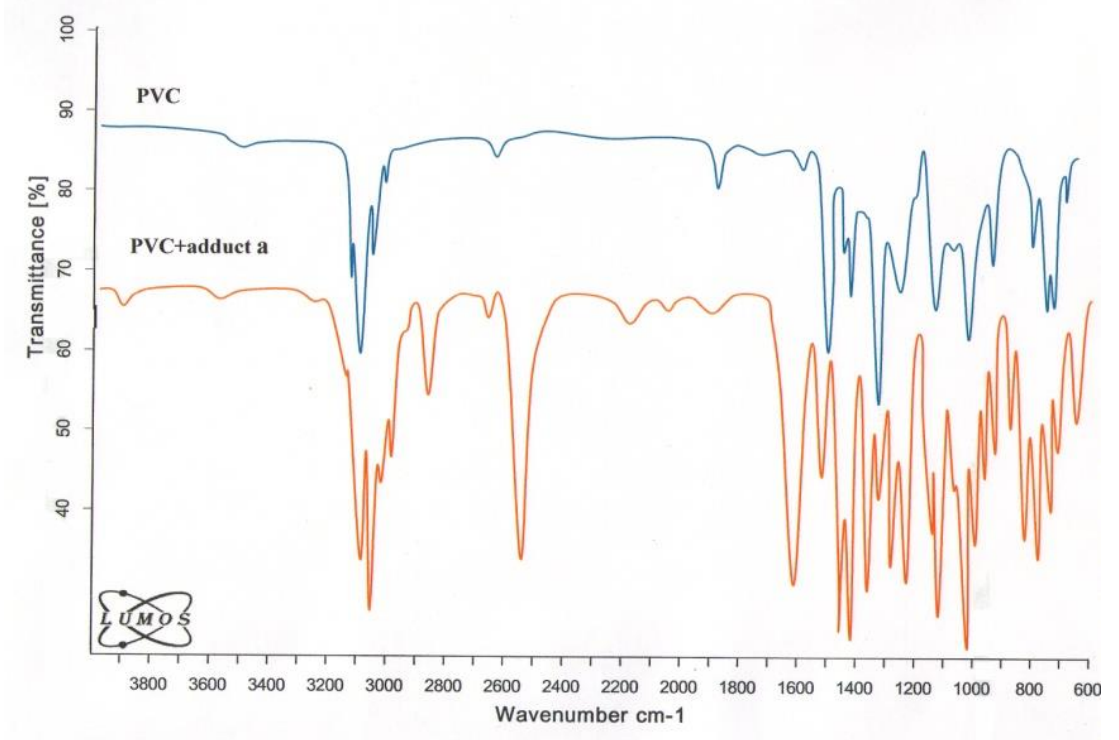

Fig. 2. IR spectrum of the initial PVC and stabilized by 2.0 mass p. of adduct

Since there were glycidyl groups, cyclopropane fragments, and also ether bonds and sulfur atoms in the structure of the obtained adducts, we tried to use them as functional additives for improvement of properties such as thermal stability, color stability and biological resistance. The compositions on the basis of PVC made by us contained 40 mass $p$. of the plasticizer of dioctyl phthalate (DOPh) per 100 mass p. of PVC, complex stabilizer stabilizers stearate $\mathrm{Ca}$ 1,5 mass p., $\mathrm{Zn}$ - stearate $\mathrm{Ca}$ 1,5 mass p. and 2,0 mass.p. of the sulphurcontaining adduct of epoxycyclopropane as costabilizer. As is known, $\mathrm{Ca} / \mathrm{Zn}$ stearates are mainly used for improvement of thermal indices, moreover, they are stabilized due to the synergistic action of both components, providing short-term $(\mathrm{Zn})$ and long-term $(\mathrm{Ca})$ thermal stability. Moreover, $\mathrm{Ca} / \mathrm{Zn}$-stearates are less toxic in comparison with stearates of other metals [19]. They are usually used jointly with organic phosphites and epoxide stabilizers for improvement of the overall operational stability of the composition. In turn, the epoxide compounds were effective as non-toxic costabilizers. Their stabilizing action came from the ability to bind hydrogen chloride; in this case, they could provide the long-term thermal stability and atmosphere resistance of PVC products. The plasticizers used in the composition of PVC compositions (DOPh or DOS) also had a good stabilizing ability [20]. The effective stabilizing activity of the synthesized adducts was determined by their influence on the temperature of the beginning of decomposition of the compositions (at a certain heating rate), on the duration of the induction period (Table.2) and $\mathrm{HCl}$ isolation rate (in $\mathrm{mg}$ of $\mathrm{HCl}$ per $1,0 \mathrm{~g}$ of the composition) for $3 \mathrm{~h}$ at temperature $180^{\circ} \mathrm{C}$ (Fig.2).

Table 2. Influence of adducts $\mathbf{a}$ and $\mathbf{b}$ on change of induction period at various temperatures and destruction rate in the compositions on the basis of plasticized PVX.

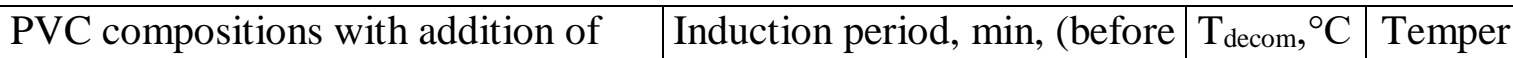
sulphur-containing adducts beginning of isolation of $\mathrm{HCl}$ ) (heating ature of 


\begin{tabular}{|c|c|c|c|c|c|c|c|}
\hline $\begin{array}{c}\text { Code of the } \\
\text { composition }\end{array}$ & $\begin{array}{c}\text { Epoxide } \\
\text { number }\end{array}$ & $\begin{array}{c}\text { Sulphur } \\
\text { content in } \\
\text { adduct }\end{array}$ & $150^{\circ}$ & $175^{\circ}$ & $190^{\circ}$ & $\left.5^{\circ} \mathrm{C} / \mathrm{min}\right)$ & $\begin{array}{c}5 \% \\
\text { loss } \\
\text { mass, } \\
\epsilon \mathrm{C}\end{array}$ \\
\hline $\mathrm{PVC}$ & - & - & 38 & 11 & - & - & - \\
\hline $\mathrm{PVC}+\mathrm{DOPh}$ & - & - & 20 & 6 & - & 168 & 172 \\
\hline $\begin{array}{c}\mathrm{PVC}+\mathrm{DOPh}+ \\
\left(\mathrm{CaSt} \mathrm{ZnSt}_{2}\right)\end{array}$ & - & - & 95 & 83 & 44 & 191 & 198 \\
\hline $\begin{array}{c}\mathrm{PVC}+\mathrm{DOPh}+ \\
\left(\mathrm{CaSt}_{2} / \mathrm{ZnSt}_{2}\right)+\mathbf{a}\end{array}$ & 23.18 & 8.58 & 119 & 98 & 50 & 196 & 202 \\
\hline $\left.\begin{array}{c}\mathrm{PVC}+\mathrm{DOPh}+ \\
\left(\mathrm{CaSt}_{2} / \mathrm{ZnSt}\right.\end{array}\right)+\mathbf{b}$ & 28.29 & 10.52 & 136 & 115 & 56 & 212 & 223 \\
\hline
\end{tabular}

It follows from the data in Table 2 that the sulfur-containing adducts with geminal glycidyloxymethyl groups in the structure of compositions made from plasticized PVC exhibit greater stabilizing activity in comparison with compositions not containing adducts. In the absence of co-stabilizers, the induction period for PVC plasticized with $\mathrm{DOPh}$ at $175^{\circ} \mathrm{C}$ is 6 min. The introduction of complex stabilizers of $\mathrm{Ca} / \mathrm{Zn}$-stearates and 2,0 mass p. of the sulfurcontaining adduct of epoxycyclopropane $\mathbf{a}$ or $\mathbf{b}$ into structure of composition of composites led to an increase in the induction period from 6 $\mathrm{min}$. to $115 \mathrm{~min}$, and an increase in some epoxide groups led to a decrease in the dehydrochlorination process rate (Fig.3). Apparently, glycidyl groups existing in the structure of adducts serve as acceptors of the isolated hydrochloric acid, inhibiting the chain reaction of dehydrochlorination of PVC macromolecules. It should be noted that the sulfur-containing tin-organic stabilizers (organosulfur compounds of stibium are used in synergic mixtures for stabilization of color) are often used for thermal stabilization of PVC (transparent, colorless rigid products - films and plates) [21]. The availability of sulfur atoms in the structure of the adducts synthesized by us, apparently, also favors the additional thermal stabilization of PVC.

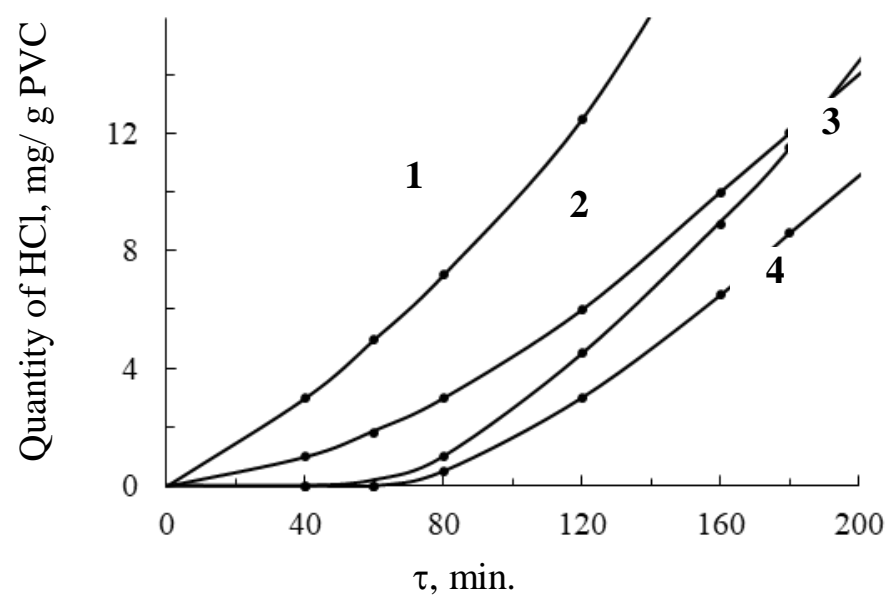

Fig. 3. Kinetics of isolation of $\mathrm{HCl}$ at heating $\left(180^{\circ} \mathrm{C}\right)$ of the initial PVC (1), plasticized (40 mass p. of DOPh) (2), plasticized and stabilized with $\mathrm{Ca} / \mathrm{Zn}$-stearates (1,5/1,5 mass p.) with addition of 2 mass p. of adduct $\mathbf{a}(3)$ and $\mathbf{b}(4)$.

In Table 3 a number of physicalmechanical, thermal and other characteristics of compositions on the basis of PVC plasticized with $\mathrm{DOPh}$ and stabilized with a mixture of $\mathrm{Ca} / \mathrm{Zn}$-stearates and sulfur-containing adducts a and $\mathbf{b}$ is presented. The study of the strength properties of the made compositions showed that the presence of the sulfur-containing adducts $\mathbf{a}$ and $\mathbf{b}$ does not deteriorate their mechanical properties. These compositions had good resistance in water and mineral oil, but they showed less resistance in a medium of 
petrol and ethanol. The migration of adducts from the matrix of PVC compositions to polyethylene at temperature $70^{\circ} \mathrm{C}$ for 5 days was insignificant. It has been established in determination of the water absorption of the compositions that after holding samples with adducts in distilled water at room temperature for $24 \mathrm{~h}$, the weight of the samples practically did not change (see Table 3). The water absorption of these compositions in hot water was $0.20-0.28 \%$. The total mass losses are
$0.32 \%$. The change of the samples mass in their holding in cold and boiling water can be the result of two opposite processes: an increase of mass due to swelling of the samples in water and a decrease of mass as a result of washing of its separate components. In this case, there may be a slight washing of the co-stabilizer from the composition, which was due to the availability of polar SH- and - $\mathrm{C}-\mathrm{O}-\mathrm{C}$-groups in the adduct molecule, favoring its partial washing with water.

Table 3. Some properties of compositions made on the basis of PVC, plasticized and stabilized with sulphur-containing adducts $\mathbf{a}$ and $\mathbf{b}$.

\begin{tabular}{|c|c|c|c|c|}
\hline \multirow[b]{2}{*}{ Name of indices } & \multirow[b]{2}{*}{$\begin{array}{l}\mathrm{PVC}+ \\
\mathrm{DOPh}\end{array}$} & \multirow{2}{*}{$\begin{array}{c}\mathrm{PVC}+ \\
\mathrm{DOPh}+ \\
\mathrm{CC}^{*}\end{array}$} & \multicolumn{2}{|c|}{$\begin{array}{l}\text { Compositions on the basis of } \\
\text { PVC and adducts** }\end{array}$} \\
\hline & & & $\begin{array}{c}\text { PVC+ } \\
\mathrm{DOPh}+ \\
\mathrm{CC}+\mathbf{a}\end{array}$ & $\begin{array}{c}\text { PVC+ } \\
\mathrm{DOPh}+ \\
\mathrm{CC}+\mathbf{b}\end{array}$ \\
\hline Tensile strength, $\mathrm{MPa}$ & 19.0 & 18.5 & 18.6 & 18.4 \\
\hline Specific elongation at break, $\%$ & 250 & 245 & 250 & 245 \\
\hline Tensile modulus of elasticity, MPa & 11.8 & 11.7 & 11.7 & 11.6 \\
\hline Decomposition temperature, ${ }^{\circ} \mathrm{C}$ & 168 & 171 & 177 & 194 \\
\hline $\begin{array}{l}\text { Critical dissolution temperature, } \\
{ }^{\circ} \mathrm{C} * * *\end{array}$ & $116-118$ & $124-128$ & $\begin{array}{c}131-133 \\
(0.13)\end{array}$ & $\begin{array}{c}133-135 \\
(0.11)\end{array}$ \\
\hline $\begin{array}{l}\text { Volatiles }\left(100^{\circ} \mathrm{C}, \quad 1 \quad \mathrm{~h} \text { under }\right. \\
\text { vacuum }), \%\end{array}$ & 0.31 & 0.30 & 0.34 & 0.31 \\
\hline $\begin{array}{l}\text { Water absorption, } \% \\
\text { in cold water (for } 24 \mathrm{~h} \text { ) } \\
\text { in boiling water (for } 30 \mathrm{~min} \text { ) }\end{array}$ & $\begin{array}{l}0.24 \\
0.46 \\
\end{array}$ & $\begin{array}{l}0.22 \\
0.48 \\
\end{array}$ & $\begin{array}{l}0.20 \\
0.20 \\
\end{array}$ & $\begin{array}{l}0.22 \\
0.28 \\
\end{array}$ \\
\hline $\begin{array}{l}\text { Migration to polyethylene at } \\
70^{\circ} \mathrm{C} \text { for } 5 \text { days, } \%\end{array}$ & 0.72 & 0.52 & 0.65 & 0.61 \\
\hline Fungal stability, points & - & 2 & 1 & 0 \\
\hline
\end{tabular}

The fungal stability of PVC compositions with the participation of adducts a and $\mathbf{b}$ was also investigated. For this, the samples with a diameter of $8 \mathrm{~mm}$ were infected with a suspension of fungal spores in water. Petri dishes with infected samples were kept for 28 days at $23 \pm 1{ }^{\circ} \mathrm{C}$ at relative humidity of more than $90 \%$. At the end of this period, the degree of fungi growth on film coatings was estimated in keeping with a 6-point scale.

The investigation of the duration of thermal action (for $3 \mathrm{~h}$ ) on the color change of
PVC compositions with the use of sulfurcontaining adducts of epoxycyclopropanes a and $\mathbf{b}$ has been investigated. During heating of the compositions samples at $180^{\circ} \mathrm{C}$ for $30 \mathrm{~min}$. (Table 4), there was observed an insignificant change of color of the samples containing epoxycyclopropane adducts (up to 9 units on $18 \mathrm{~s}$ point Gardner scale) besides $\mathrm{Ca} / \mathrm{Zn}$ stearates. During further heating of the samples (higher 90-120 $\mathrm{min}$ ), the stabilizing action of adducts was decreased, and the samples were intensively painted. 
Table 4. Color change of PVC samples plasticized with DOPh and stabilized with sulfur-containing adducts of epoxycyclopropanes $\mathbf{a}$ and $\mathbf{b}$ depending on the heating duration at $180^{\circ} \mathrm{C}$.

\begin{tabular}{|c|c|c|c|c|c|c|}
\hline \multirow{3}{*}{\begin{tabular}{c} 
Compositions \\
\cline { 2 - 6 }
\end{tabular}} & \multirow{2}{*}{ Medium } & \multicolumn{5}{|c|}{ Coloring on the Gardner scale (from 1 to 18 units) } \\
\cline { 3 - 7 } & & \multicolumn{5}{|c|}{ Sample heating time, min } \\
\cline { 2 - 7 } Initial PVC & air & 9 & 60 & 90 & 120 & 150 \\
\cline { 2 - 7 } & nitrogen & 7 & 11 & 16 & 18 & - \\
\hline \multirow{2}{*}{ PVC+DOPh+CC } & air & 5 & 8 & 13 & 16 & 18 \\
\cline { 2 - 7 } & nitrogen & 5 & 6 & 13 & 14 & 18 \\
\hline $\begin{array}{c}\text { PVC+DOPh+CC+ } \\
\text { adduct a }\end{array}$ & air & 6 & 7 & 11 & 15 & 18 \\
\cline { 2 - 7 } & nitrogen & 5 & 7 & 10 & 13 & 16 \\
\hline $\begin{array}{c}\text { PVC+DOPh+CC+ } \\
\text { adduct b }\end{array}$ & air & 6 & 8 & 11 & 16 & 18 \\
\cline { 2 - 7 } & nitrogen & 4 & 7 & 9 & 14 & 16 \\
\hline
\end{tabular}

The color resistance of the composition samples with adducts can be explained by the interaction of epoxide groups of adducts with $\mathrm{HCl}$ isolated during heating, however, it should not be excluded that the color stability of compositions might also be connected with the catalytic action of epoxycyclopropane adducts on polyene structures, or with the catalytic oxidation of polyene structures in the stabilization process of PVC. This was shown by the availability of the oxygen-containing fragments $(-\mathrm{OH},-\mathrm{O}-,-\mathrm{C}=\mathrm{O}$, etc. $)$ in the IR spectra of PVC during heating in air, during heating of the samples in nitrogen, these fragments are not observed in the spectra.

\section{Conclusions}

The results of the investigations showed that the introduction of calcium-zinc-stearates as complex stabilizers and sulfur-containing adducts of gem-disubstituted epoxycyclopropanes with thiols as co-stabilizers into the structure on the basis of PVC compositions leads to rise in the thermal stability of the compositions. At the same time, the indices of color resistance of compositions are improved during their heating for $3 \mathrm{~h}$ at $180^{\circ} \mathrm{C}$. The obtained data also testify to the fact that the compositions made with sulfurcontaining adducts acquire fungal resistance. Thus, the structural peculiarity of the synthesized adducts allows to assume the possibility of use of the sulfur-containing epoxycyclopropane adducts as additives to PVC in the formation of compositions differing with thermal stability, good color stability and fungal resistance (for example, antimicrobial coatings or hygienic packaging), when good elasticity, high strength and biostability are required.

\section{References}

1. Balakrishnan B., Jayakrishnan A. Chemical modification of poly (vinyl chloride using poly ethylene glycol to improve blood compatibility. Trends in Biomaterials and Artificial Organs. 2005, vol.18, no. 2, pp. 230-236.

doi:10.1016/j.biomaterials.2004.09.032

2. Kenawy E.R., Worley S.D., Broughton R. The chemistry and Applications of Antimicrobial Polymers: A State-of-the-Art
Review. Biomacromolecules, 2007, vol. 8(5),pp.1359-1384.

doi.org/10.1021/bm061150q

3. Wilkie Ch., Summers J., Daniels Ch. Polyvinyl chloride. Translated from English. edited by G.E.Zaikov. St.Peterburg: Profession Publ., 2007, 728 p.

4. Bashta B., Brostow W., Granowski G., Hnatchuk N. Modification of Poly(Vinyl Chloride) + Epoxy Systems for Improved 
Thermal and Aging Stability. Macromolecular Symposia, 2016, vol. 365, is.1 - Spec. Is.: POLYCHAR 23 World Forum on Advanced Materials. pp.239-245.

doi.org/10.1002/masy.201650023

5. Ji J. Bacterial behaviors on polymer surfaces with organic and inorganic antimicrobial compounds. J. Biomed. Mater. Res. A, 2009, no. 88, pp. 448-453. doi.org/10.1002/jbm.a.31759

6. Onichko V.I. PVC compositions: compositions and preparation. Polymer Materials. 2003, no.11, pp.12-14. (In Russian). http://www.polymerbranch.com/

7. Guzeev V.V. Rational choice of additives for PVC compositions. Polymer materials. 2010, no. 7-8, pp. 38-48. (In Russian).

8. Badrossamay M., Gang Sun. Enhancing hygiene/antimicrobial properties of polyolefins. Polyolefine fibres. 2017, Chapter 8, pp. 265-284. doi.org/10.1016/ B978-0-08-101132-4.00008-4

9. Zhubanov B.A., Batyrbekov E.O., Iskakov R.M. / Polymer materials with therapeutic action (Monography). Almaty: Complex 2, 2000, $220 \mathrm{p}$.

10. Shahnazarli R.Z., Ramazanov G.A., Guliyev A.M. / Plastics with special properties. Collection of scientific papers. Sec.3. New polymer materials with special properties. Saint-Petersburg, 2011, pp. 259261. ISBN 978-5-91884-032-0

11. Shahnazarli R. Adducts of thiols with allylcyclopropoylmethyl ethers - biocide additions for polyvinyl chloride. $/ / 4^{\text {th }}$ International Polymeric Composites Symposium, Exhibition \& Brokerage Event "IPC-2015", Izmir, Turkey, CD (PK-025)

12. Abdel-Monem R.A., El-Sayed A.A., Abdelhamid A.E., Rabie S.T. Adenine functionalized antibacterial PVC with both photo and thermal stability. J. vinyl and additive technology. 2021, vol. 27, is. 3 , pp. 555-566. doi.org/10.1002/vnl.21827

$\begin{array}{ll}\text { 13. Munoz M., El-Khoury } & \text { A., Cimenci } \\ \text { C.E., Gonzalez-Gomez } & \text { M., Hunter }\end{array}$
R.A., Lomboni

D., Variola

F., Rotstein

B.H., Vono

L.L.R.,

Rossi

L.M., Edwards A.M., Alarcon E.I.

Riboflavin Surface Modification of Poly(vinyl chloride) for Light-Triggered Control of Bacterial Biofilm and Virus Inactivation. ACS Appl Mater Interfaces, 2021, vol.13, is.27, pp. 32251-32262. doi: 10.1021/acsami.1c08042

14. Folarin O.M., Sadiku E.R. Thermal stabilizers for poly(vinyl chloride): A review. Int. J. Phys. Sci. 2011, vol.6 (18), pp. 4323-4330. doi: 10.5897/IJPS11.654

15. Shahnazarli R.Z., Guliyev A.M. Synthesis and radical polymerization of glycidyloxycarbonyl- and glycidyloxymethyl substituted vinyloxycyclopropanes. "International innovation research": collection of articles of VI Inter. Scientific- pract Conf. Edited by G.Y.Gulyaev. Penza: ICNS "Science and Education". 2017, p.26-32. ISBN 978-59909511-2-9.

16. Shahnazarli R.Z., Hasanova S.S., Guliyev A.M. Chlorocyclopropane-containing sul fides - additives to lubricating oils. Petrochemistry, 2006, vol. 46, no. 3, pp.1-4.

17. Workshop on polymer materials science. Edited by P.G.Babaevsky. - Moscow: Chemistry Publ., 1980, 256 p.

18. GOST 14332-78. Polyvinyl chloride suspension (technical conditions). Moscow: Publishing House of standards, 1984.

19. Foigt I. Stabilization of synthetic polymers against the action of light and heat. / Edited by B.M.Kovarskaya. Leningrad, Publishing House "Chemistry", Leningrad branch, 1972, $544 \mathrm{p}$.

20. Barstein R.S., Kirilovich V.I., Nosovsky Yu.E. Plasticizers for polymers. Moscow: Chemistry Publ.,1982. 200 p.

21. Patent US-4336168-A. Inventor: Hoch S., Ceprini M.Q. Stable liquid antimony stabilizer compositions and vinyl halide resins containing same. 1980/04/28. https://patents.google.com/patent/US43361 $\underline{68 \mathrm{~A}}$ 


\title{
PVX-NIN TERMOSTABILLOŞMOSI ÜÇÜN OVOZOLUNMUŞ VINILOKSITSIKLOPROPANLARIN TIOLLARLA ADDUKTLARI
}

\author{
R.Z. Şahnəzərli \\ Azarbaycan Milli Elmlor Akademiyasının Polimer Materialları Institutu \\ Az 5004, Sumqayıt, S.Vurgun, 124, e-mail: shahnazarli@mail.ru
}

Tarkibindo plastifikator kimi dioktilftalat, kompleks termostabilizator kimi kalsium vo sink stearatlart saxlayan PVX asasında kompozisiyalar hazırlanmışdır. Hem-diqlisidiloksimetil avozolunmuş tsiklopropilvinil efirinin tiofenol vo etanditiolla adduktları kompozisiyaların torkibindo birgastabilizatorlar va biosid alavalor kimi istifado edilmişdir. Hazırlanmış kompozisiyaların termiki xüsusiyyətlari tədqiq olunmuşdur. Kompozisiyanın termiki stabilliyina va ranginin dəyişməsinə sintez olunmuş kükürd saxlayan adduktların təsiri öyronilmiş vo PVX kompozisiyasının tərkibində adduktların göbalak aleyhinə test nümunalari yoxlanılmışdır. Müəyyən olunmuşdur ki, adduktlar kompozisiyanın tarkibina daxil edildikdən sonra onların kimyəvi quruluşlarında asaslı dəyişikliklar baş vermomişdir. Adduktların iş̧irakı ilo hazırlanmış kompozisiyaların istiliyo qarşı davamlıliğl, rang stabilliyi va göbalay aleyhinə xassalari yaxşılaşmışdır.

Açar sözlor: viniloksitsiklopropan, etanditiol, tiofenol, addukt, polivinilxlorid, kompozisiya, termostabillik, rang stabilliyi, göbalayə qarşı davamlılıq.

\section{АДДУКТЫ ЗАМЕЩЕННЫХ ВИНИЛОКСИЦИКЛОПРОПАНОВ С ТИОЛАМИ В КАЧЕСТВЕ ТЕРМОСТАБИЛИЗАТОРОВ ПВХ}

\section{P.3. Шахназарли}

Институт полимерных материалов Национальной АН Азербайджана AZ 5004, Сумгаит, ул. С. Вургуна, 124. e-mail: shahnazarli@mail.ru

Разработань композиции на основе ПВХ, содержащче диоктилфталат в качестве пластификатора, комплексные термостабилизаторы - стеарать кальция и цинка, $u$ аддукты тиофенола и этандитиола $с$ гем-диглищидилоксиметилзамещенным циклопропилвиниловым эфиром в качестве со-стабилизаторов и биочидных добавок. Исследованы термические свойства разработанных композииий: изучено влияние синтезированных серосодержащих аддуктов на термическую стабильность и изменение окраски композиций. Проведень тесты на выявление противогрибковой активности аддуктов в составе ПВХ-композищий. Найдено, что, химическая структура аддуктов после введения в состав композиций существенно не меняется. Композиции с участием аддуктов в качестве со-стабилизаторов приобретают улучшенные показатели по теплостойкости, иветостабильности и противогрибковой активности.

Ключевые слова: винилоксициклопропан, этандитиол, тиофенол, аддукт, поливинилхлорид, композиция, термостабильность, ияветостабильность, грибостойкость. 